\title{
Leukodystrophy with premature ovarian failure: think on vanishing white matter disease (VWMD)
}

\author{
Leucodistrofia com falência ovariana prematura: pense na doença da substância branca \\ evanescente \\ Fernando Freua, Jacy Bezerra Parmera, Denise de Oliveira Doria, Anderson Rodrigues Brandão de Paiva, \\ Lucia Ines Macedo-Souza, Fernando Kok
}

A 46-year-old female presented progressive hand tremor at age of 8 , associated to cognitive and motor deterioration. She developed incapacitating head tremor and was wheelchair-bound 12 years after onset. Premature ovarian failure (POF) occurred at 27-year-old. In the last 3 years, head tremor became less intense, but she remained with horizontal bidireccional nistagmus.

Vanishing white matter disease (VWMD) is an autosomal recessive disorder characterized by cerebellar ataxia, spasticity, and cognitive impairment ${ }^{1,2}$. Brain MRI discloses symmetric and diffuse white matter lesions (figure). VWMD manifests from infancy to adulthood; in female, POF may occur $^{3}$. It is caused by mutations in both alleles of one of five genes coding for subunits of eukaryotic translation initiation factor $2 \mathrm{~B}$.
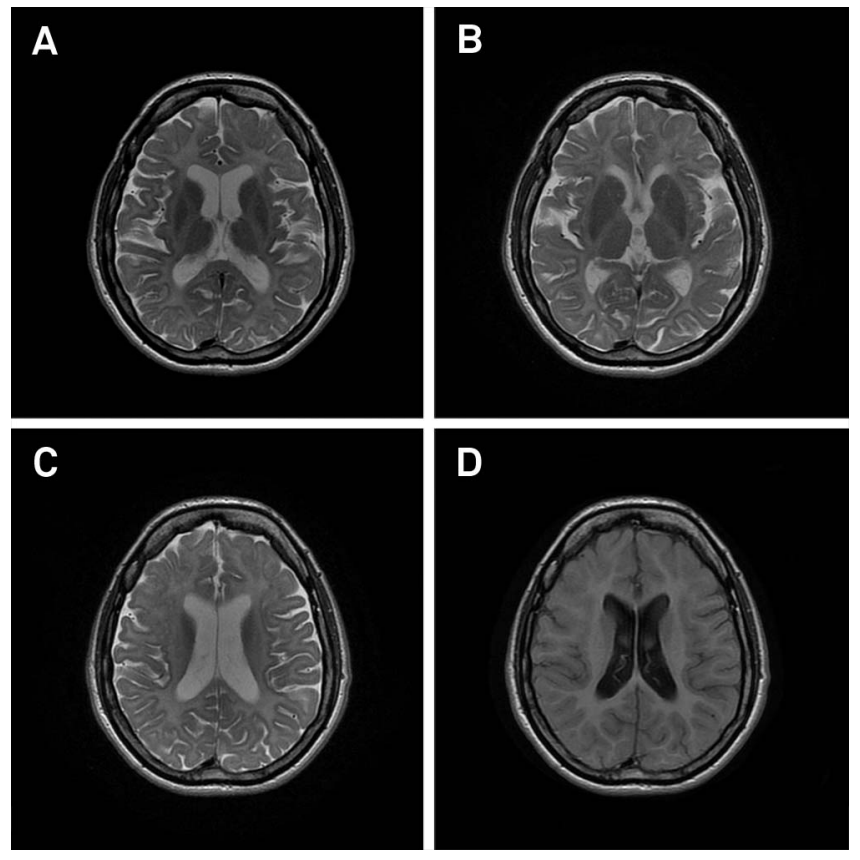

Figure. (A, B, and C) T2-weighted acquisition showing diffuse abnormal white matter signal, with intensity close to of the cerebrospinal fluid; and (D) Fluid-attenuated inversion recovery (FLAIR), showing diffuse hyperintensity in white matter.

\footnotetext{
1. Knaap MS, Kamphorst W, Barth PG, Kraaijeveld CL, Gut E, Valk J. Phenotypic variation in leukoencephalopathy with vanishing white matter. Neurology. 1998;51(2):540-7.

2. Costello DJ, Eichler AF, Eichler FS. Leukodystrophies: classification, diagnosis, and treatment. Neurologist. 2009;15(6):319-28. http://dx. doi.org/10.1097/NRL.0b013e3181b287c8
}

3. Schiffmann R, Tedeschi G, Kinkel RP, Trapp BD, Frank JA, Kaneski CR et al. Leukodystrophy in patients with ovarian dysgenesis. Ann Neurol. 1997:41(5):654-61.

\footnotetext{
Hospital das Clínicas, Faculdade de Medicina, Universidade de São Paulo, Sao Paulo SP, Brazil.

Correspondence: Fernando Freua; Rua Nestor de Barros, 116 / cj. 95; 03325-050 São Paulo SP, Brasil; E-mail: fernando.freua@gmail.com Conflict of interest: There is no conflict of interest to declare.
}

Received 04 August 2014; Received in final form 02 September 2014; Accepted 22 September 2014. 